\title{
PRIMENA I ZNAČAJ TEORIJE VEROVATNOĆE ZA SIGURNOST BETONSKIH KONSTRUKCIJA
}

Vojislav Mihailović1

УДК: 624.046:519.21

DOI: 10.14415/zbornikGFS27.06

Rezime: Osnovni koncepti analize sigurnosti betonskih konstrukcija su prikazani preko više metoda aktuelnih i primenjenih u praksi.

Cilj rada je da se preciziraju mogućnosti dosadašnjih metoda analize sigurnosti i domeni njihove primene. Uporedno se daje gledanje na pouzdanost betonskih konstrukcija

Ključne reči: Sigurnost konstrukcija, teorija verovatnoće, pouzdanost

\section{UVOD}

Model tehničkih propisa CEB-FIP 1978. je doneo nove norme za projektovanje i građjenje konstrukcija. Tendencija konstruktera u više evropskih zemalja je bila da se predstavnici nacionalnih institucija za izradu propisa, zajedno sa inženjerima projektantima i izvođacima radova, predlože norme i preporuke, koje bi bile obavezujuće za sto širi krug zemalja.

Iako je angažovan vrlo veliki broj timova, kasnije pod nazivom Komisija za pojedine oblasti konstrukcija, već 2000. godine pojavila se potreba za novim promenama i dopunama modela koda pod nazivom Evrokod (EC2). Pored toga, uočene su specifične potrebe pojedinih zemalja, koje su prevaziđene. usvajanjem nacionalnih dokumenata pod sažetim nazivom NAD. Ovi dokumenti bi privremeno važili za pojedinačne zemlje

Evrope. Poslovi stvaranja Evrokodova počeli su da se razvijaju i primenjuju za druge materijale i probleme što je znato povećalo obim istraživanja .

Cilj ovog rada je da se preko postupaka rada na dimenzionisanju AB i PB preseka, koji su primenjivani, pre svega, u Evropskim zemljama, USA i Rusiji sažeto prikažu zbog ograničenog prostora, ali da se može pratiti put za donošenje novih propisa. Novi postupci proračuna uključuju analizu dve grupe podataka .

Prva grupa se odnosi na primenu teorije verovatnoće za ocenu kvaliteta materijala i mogućih grešaka u radu, a druga se odnosi na ocenu sigurnosti i pouzdanosti konstrukcija. U 1978.g. je objavljen na srpskom jeziku, u izdanju DGA, predlog normi CEB-FIP koji sadrži dva dela:

\footnotetext{
${ }^{1}$ Prof. dr Vojislav Mihailović (u penziji), dipl inž građ., Građevinski fakultet Subotica, Kozaračka 2a, tel: 554-300, e -mail : voja@gf.uns.ac.rs:

CEB- Evropski komitet za beton ; FIP - Internacionalna federacija za prednaprezanje AB - Armirani beton ; PB -Prednapregnuti beton
} 
I. Jedinstvena opšta pravila za različite tipove konstrukcija i materijala

II. Model propisa za AB i PB konstrukcije.

Evrokodovi sadrže ova dva dela pod oznakom EC1 i EC2 . Pored toga, sadrže još sedam delova , koji razmatraju dejstva na konstrukcije, delovi za glavne građevinske materijale, seizmička i geomehička dejstva i konstrukcije. Posle usklađivanja svih dokumenata NAD donele bi se Evropske norme sa oznakom EN za koje se, za sada ,ne može lako prevideti kada će biti usvojene.

U ovom radu biće obrađeni delovi samo EC2 za AB i PB konstrukcije.

\section{METODA DOPUŠTENIH NAPONA $\left(P^{\prime}, 47\right)^{2}$}

Metod projektovanja AB konstrukcija za radna opterećenja (service load) počeo je da se razvija radovima Koenena(1886)[6].

Klasična definicija dopuštenog napona se daje preko izraza za beton

$$
\sigma_{c, a d m}=\frac{f_{c k}}{\gamma_{c}}
$$

i za čelik

$$
\sigma_{s, a d m}=\frac{f_{Y}}{\gamma_{s}}
$$

Ako se uporede vrednosti za središnji napon u stubovima prema našim propisima za $\mathrm{AB}$ je $\sigma_{\mathrm{c}}=0.2 f_{c k}^{\prime}$ ili $\gamma_{\mathrm{c}}=5$, a za grede $\sigma_{\mathrm{c}}=0.40 f_{c k}^{\prime}$ ili $\gamma_{\mathrm{c}}=2.5$.

Za čelik $f_{Y}^{\prime}=24 \mathrm{MPa}$ u gredama je $\sigma_{\mathrm{sc}}=0.67 f_{s k}^{\prime}$ ili $\gamma_{\mathrm{c}}=1.7$.

Medjutim, poznato je AB stubovi po teoriji loma imaju koeficijent sigurnosti između 1.9 do 2.1 , a za grede vrednost izmedju 1.5 i 1.8, što je u saglasnosti sa našim propisima i našim eksperimentalnim podacima.

Ako upredimo vrednosti prema dopuštenim naponima sa vrednostima prema teoriji loma vidi se da prva teorija daje prividne koeficijente sigurnosti, koji se znatno razlikuju od eksperimentalnih . Zato se razvila teorija loma, koja treba što bolje da opiše ponašanje AB elemenata pri lomu.

Teorija dopuštenih napona nije izgubila ništa od svog značaja, iako se u nekim radovima tvrdi da je 'neadekvatna'(npr. u radu[ 9]na st 102).

Teorija dopuštenih napona je osnovna za analizu sledećih zadataka:

1. U prethodno napregnutih konstrukcijama je potrebno precizno poznavati sile zatezanja kablova za sve faze izvođenja;

${ }^{2}$ P' 47 - Propisi YU 1947

70 | JOURNAL OF FACULTY OF CIVIL ENGINEERING 27 (2015) | 
2. Za spregnute konstrukcije treba poznavati sile u vezama i deformacijsko stanje elemenata sa uticajem elstičnog ponašanja zajedno sa tečenjem i skupljanjem betona (Ovo ,takođe, važi za Montažne AB konstrukcije).

3. Problemi stabilnosti konstrukcija. Poznato je da gubitak ravnoteže vitkih elementa može nastati i pri malim naponima [6 ];

4. Analiza dinamičkih opterećenja treba da bude urađena za radna opterećenja. Poseban značaj ima, radi kontrole, stanje promena krutosti preseka radi donošenja odluka o stepenu intervencija na otklanjanju oštećenja elemenata;

5. Zamor konstrukcija ili elemenata usled višeciklićnih promena opterećenja;

6. Praćenje ponašanja konstrukcija u karakterističnim presecima praćenjem ugiba, dilatacija i okretanja i primena savremenih senzora za merenja napona.

Već u fazi analize, pomoću teorije dopuštenih napona, korisnije je kvalitet materijala proceniti na osnovu teorije verovatnoće, iako se radi o potpuno determinističkoj teoriji proračuna. Alternativno čvrstoća uzoraka betona je utvrđena normama ( $\left.\mathrm{P}^{\prime} 47\right)$ kao srednja vrednost, ali pojedinačna odstupanja mogla su da budu čak $25 \%$.

\section{METODA GLOBALNOG KOEFICIJENTA SIGURNOSTI (P'71)}

Metoda se u USA naziva metodom faktora sigurnosti za opterećenje. Našim propisi su bazirani na našim iskustvima i eksperimentima obaljenim u Nemačkoj , Rusiji, Mađarskoj i na značajnim doprinosima Francuske. Za istorijski prikaz treba istaći izvanredan značaj rada [8 ]. U tom radu su prikazana i iskustva Mađarske u primeni metode parcijalnih koeficijenata tokom 50 godina . Razmatrane su, osim sigurnosti i uslovi za pozdanost konstrukcija u dokumentu 'EN 0, zasnovanog na EN 1990, u kome su dati principi projektovanja $\mathrm{AB}$ i $\mathrm{PB}$ konstrukcija. Zaključeno je da metoda parcijalnih

koeficijenata sigurnosti je bazirana na optimalnom konceptu sigurnosti.

Radi usvajanja naših propisa iz ove oblasti obavljeni su vrlo opsežni eksperimenti u Institutu IMS pod rukovodstvom Prof. D. Jevtića. Učesnik u obimnom projektu bio je i autor ovog rada. U ovom prvom predlogu je usvojena za RDB parabola za sve slučajeve dimenzionisanja . Pojava CEB('78) preporuka i Eevrokoda EC2 uslovila je kritično razmatrnje ovog pravilnika i usvajanje novog koncepta zasnovanog na parcijalnim koeficijentma za opterećenja i materijale . Za primenu teorije verovatnoće u pravilniku iz 1971 god. važi napomena kao kod prethodne metode. Za procenu kvaliteta usvojen je fraktil $16 \%$.

\section{METODA PARCIJALNIH KOEFICIJENTA SIGURNOSTI (P'87)}

\section{a. ) Uporedjenje metode propisa P'71 i P'87}

Analiza naših eksperimentalnih vrednosti nosivosti AB nosača u IMS-u , posle pojave CEB preporuka, je pokazala da ukoliko se prihvati novi predlog RDB (parabola sa pravougaonikom), momenti loma ostaju skoro isti kao prema P'71, ako su iste vrednosti

\footnotetext{
${ }^{3} \mathrm{P}^{\prime} 87-\mathrm{PBAB}{ }^{\prime} 87$
} 
globalnog koeficijenta. Međutim, rezultati se znatno menjaju ako se uvedu i parcijalni koeficijenti za materijale, naročito ako se analiziraju sile nosivosti pri lomu elemenata. Za globalni koeficijent se može napisati [4]:

$$
\gamma_{u}=\frac{\sum \gamma_{u i} \cdot S_{i}}{S}
$$

Najcešče se usvaja $\mathrm{S}_{\mathrm{i}, \max }$ ili $\mathrm{S}_{\mathrm{i}, 95}$, gde je $\mathrm{S}_{\mathrm{i}, 95}$ vrednost fraktila potrebnog radnog uticaja usvojenog sa verovatnoćom od $95 \%$. Ovako nađena vrednost globalnog koeficijenta sigurnosti omogućava pravilnu procenu odnosa vrste uticaja na globalni koeficijent sigurnosti (v.Tabelu 1).

Upoređenja računskih i rezultata ispitivanja 51 nosača do loma, koji su bili armirani sa RA 40 - Zenica sa mehaničkim koeficijentima armiranja $\omega_{\mathrm{S}}=0.5$ do $2.3 \% \mathrm{i}$ MB 200 do 600. Rezultati su publikovani u radu [3] i dati na Sl.1.

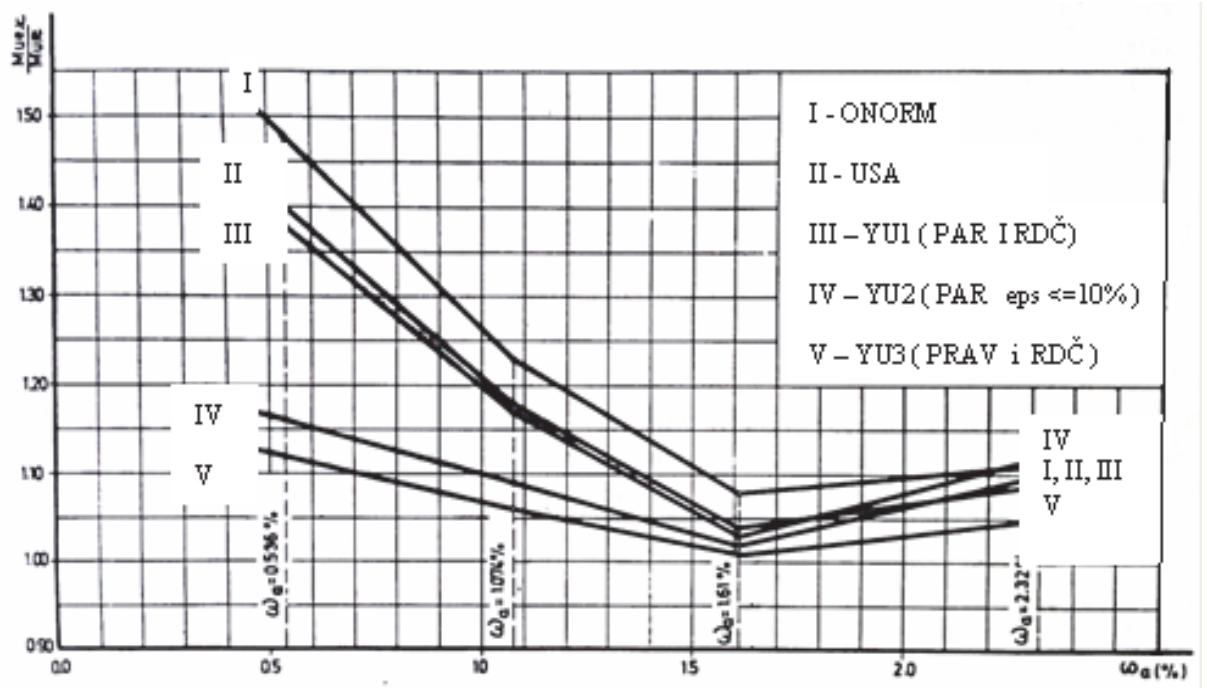

Sl.1 Zavisnost odnosa Mu,exp/ $M_{R u}$ od procenta armiranja nosača $\omega(\%)$ [ 3 ]

Kao sto se vidi na prethodnoj slici slaganja rezultata proračuna sa rezultatima eksperimnata su dosta dobra prema Austrijskim normama( ONORM 4200), Američkim normama iz 1962.g. , i za više kombinacija RDČ uzetih prema P'71.

Za srednje armirane nosače $\left(\omega_{\mathrm{s}}=1.61\right)$ i jako armirane $\left(\omega_{\mathrm{s}}=2.3\right)$ eksperimenti daju veće vrednosti do $10 \%$. Međutim, za slabo armirane preseke $\left(\omega_{\mathrm{S}}=0.53\right)$ razlike mogu biti do 50\%, ako se u proračunu koristi eksperimentalni RDČ bez ograničenja dilatacija na $10 \%$ o. Ipak ograničenje dilatacija na $10 \%$ o je ispravno, jer pri toj deformaciji nosači gube svoju funkciju zbog previše velikih ugiba .

Primena verovatnoće je ista kao i kod drugih metoda samo za materijale, ali za beton je uveden fraktil 10\%, umesto fraktila16\% koji je važio za P'71. 
Prema tome, pristup proračunu je bio potpuno deterministčki, ako su unapred postavljeni uslovi za kvalitet i odredjeno maksimlno moguće odstupanje od srednje vrednosti.

Kontrola rezultata je izvršena i u skladu sa EC2, gde je predviđen fraktil 5\% za beton i za celik. Odstupanja u odnosu na P' 71 nisu velika i značajna., ako se ne uvedu u račun parcijalni koeficijenti za materijale.

\section{b. ) Upoređenje metode propisa P'87 i EC2}

Tvrđenje A. Baker-a (1958) da konstrukcija za jedan element može imati samo jedan koeficijent sigurnosti komentarisana je šire u radovima [4 ][ 5].

Mnogi zadaci dimenzionisanja elemenata mogu se rešiti i sa parcijalnim koeficijentima sigurnosti, ali često su povoljniji globalni koeficijenti (v.str. 20 [3 ] ).

Analiza parcijalnih i globalnih koeficijenata u EC2 je detaljnije data u radu [4 ] i [ 5]. Ovde će se ponoviti samo jedan deo Tabele1 u dopunjenom delu sa formulama iz

P'87 zato što se neki podaci u predlogu malo razlikuju. Potrebni granični uticaji $S_{u}$ zavise, takođe, od kombinacije opterećenja i postignute dilatacije $\left(\varepsilon_{\mathrm{s} 1}\right)$ u armaturi Aa1.

Tabelal . Potrebni granični uticaji i globalni koeficijenti sigumosti

\begin{tabular}{|c|c|c|c|c|}
\hline Opterecenje & $\varepsilon_{\mathrm{s} 1}$ & $S_{11}$ & $y$ & Oblik \\
\hline $\begin{array}{l}\text { I } \\
\text { Stalno } \\
\text { Povremeno }\end{array}$ & $\begin{array}{l}>=3 \\
<=0 \\
(0 / 00)\end{array}$ & $\begin{array}{l}1.6+1.8 \alpha_{p} \\
1.9+2.1 \alpha_{p}\end{array}$ & $\begin{array}{l}\frac{1.6+1.8 \alpha_{p}}{1+\alpha_{p}} \\
\frac{1.9+2.1 \alpha_{p}}{1+\alpha_{p}}\end{array}$ & 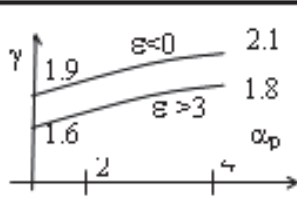 \\
\hline $\begin{array}{l}\text { II } \\
\text { Stalno } \\
\text { Povremeno } \\
\text { Dopunsko }\end{array}$ & $\begin{array}{l}>=3 \\
<=0 \\
(0 / 00)\end{array}$ & $\begin{array}{l}1.3+1.5 \alpha_{\mathrm{p}}+1.3 \alpha_{\Delta} \\
1.5+1.8 \alpha_{\mathrm{p}}+1.5 \alpha_{\Delta}\end{array}$ & $\begin{array}{l}\frac{1.3+1.5 \alpha_{p}+1.3 \alpha_{\Delta}}{1+\alpha_{p}+\alpha_{\Delta}} \\
\frac{1.5+1.8 \alpha_{p}+1.5 \alpha_{\Delta}}{1+\alpha_{p}+\alpha_{\Delta}}\end{array}$ & $\gamma \underbrace{}_{\substack{1.3 \quad g=0 \\
12}} 1.6$ \\
\hline $\begin{array}{l}\text { II } \\
\text { Stalno } \\
\text { Povremeno } \\
\text { Dopunsko }\end{array}$ & $\begin{array}{l}>=3 \\
<=0 \\
(0 / 00)\end{array}$ & $\begin{array}{l}1.3+1.2\left(\alpha_{p}+\alpha_{\gamma}\right) \\
1.7+1.5\left(\alpha_{p}+\alpha_{\gamma}\right)\end{array}$ & $\begin{array}{l}\frac{1.3+1.2\left(\alpha_{p}+\alpha_{\gamma}\right)}{1+\alpha_{p}+\alpha_{\gamma}} \\
\frac{1.7+1.5\left(\alpha_{p}+\alpha_{\gamma}\right)}{1+\alpha_{p}+\alpha_{\gamma}}\end{array}$ & 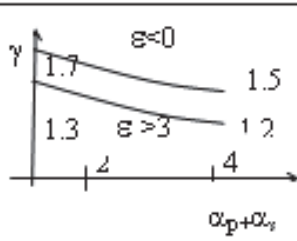 \\
\hline
\end{tabular}

Paralelno su u Tabeli 1 daje predlog izraza za granične uticaje i globalne koeficijente sigurnosti koji se mogu direktno koristiti .

U intervalu dilatacija $0<\varepsilon s 1<3$ u čeliku Aa1, koeficijent sigurnosti elementa za P'87 je

$$
\gamma_{u}=\gamma_{u}^{(0)}-\frac{\varepsilon}{3}\left(\gamma_{u}^{(0)}-\gamma_{u}^{(3)}\right)
$$


Ove diatacije treba izbegavati pri dimenzionisanju, zato što može doći do iznenadnog loma elemenata.

Treća kombinacija opterećenja u Tabeli1. je predlog autora, koja važi za slučajna dejstva : seizmička dejstva, hiljadugodišsnje vode, neočekivana pomeranja tla i dr. Koeficijenti su formirani na osnovu propisa za seizmiku, podataka iz literature i iskustva autora [3 ] [4 ].

Radi lakšeg upoređenja rezultata, glavnih propisa u svetu, biće prikazani na primeru momenata savijanja u preseku. Na Sl.2 prikazani su eksperimentalni momenti loma $\left(\mathrm{M}_{\mathrm{R} \text {,exp }}\right)$, zatim granični momenti $\left(\mathrm{M}_{\mathrm{Ru}}\right)$ i momenti prema teoriji graničnog računskog stanja $\left(\mathrm{M}_{\mathrm{d}}\right)$. Vidi se da je velika razlika u rezultatima po teoriji loma i teoriji graničnog računskog stanja . Ova razlika postoji zato sto se uticaj kvaliteta materijala uvodi samo jedaput u prvoj teoriji (usvajanjem fraktila), a u drugoj dva puta (drugi put zbog uvodjenja koeficijenta sigurnosti za materijale).

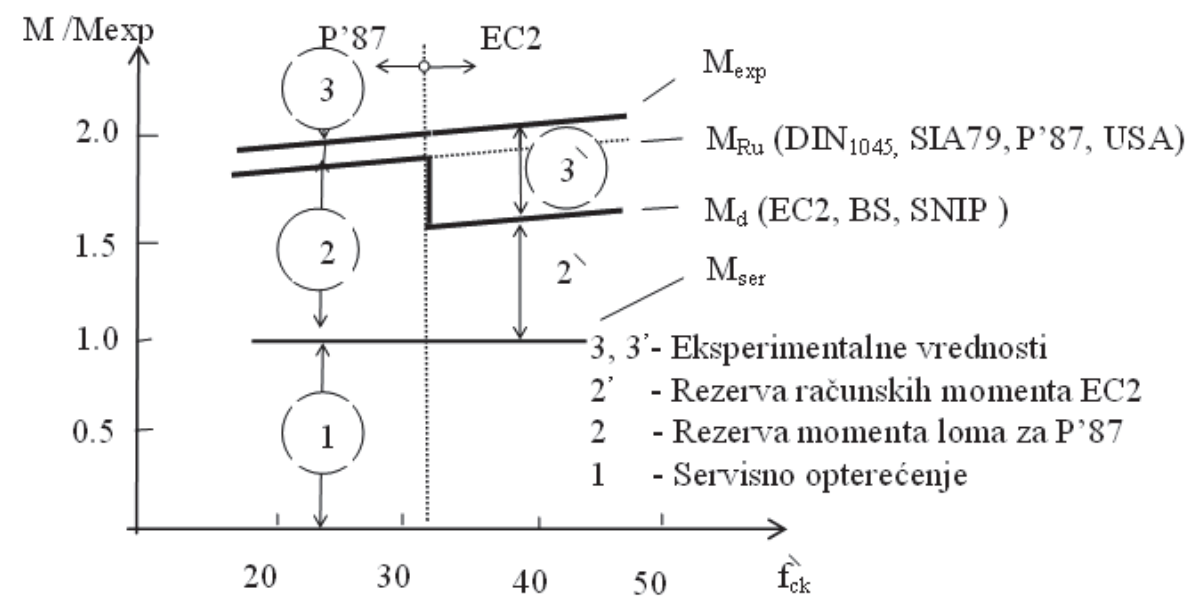

\section{Sl.2 Momenti savijanja $M_{u, e x p}$, momenata loma $M_{R u}$, računski moment $M_{d}$ i radni(servisni) moment Mserv kao funkcije čvrstoće betona}

Prema ovoj slici vidi se da presek uvek ima rezervu nosivosti, jer su koeficijenti sigurnosti od 1.6 do 2.1 za grede i stubove, ako su očuvani projektanski i izvođački uslovi u predviđenom veku trajanja konstrukcije.

Dijagrami koeficijenata sigurnosti na skicama u Tabeli 1 daju njihovu zavisnost od odnosa aktivnog opterećenja i stalnog opterećenja i može se uočiti da od tog odnosa najviše zavise vrednosti $\left(\gamma_{u}\right)$. P'87 uvodi u dimenzionisanju samo koeficijente sigurnosti za opterećenja, a posredno usvajanjem fraktila $10 \%$ za beton i $5 \%$ za čelik. Fraktili za materijale daju verovatnoće za odstupanja od srednjih vrednosti. U EC2 su usvajeni isti fraktili (5\%) za oba materijala .

Veća razlika je u usvojenim RDB i RDČ, zato što se prema P'87 uzima RDB i RDČ bez redukcije. Ovo značajno utiče na procenu dilatacija u poprečnom preseku, ukoliko se ne koristi realni RDČ u EC2, jer se menja položaj neutralne linije.

74 | JOURNAL OF FACULTY OF CIVIL ENGINEERING 27 (2015)| 
Interesantno je da se vidi koji je odnos srednje čvrstoće i fraktilne čvrstoće za oba materijala da bi zaključili koliko su povezane sa parcijalnim koeficijentima sigurnosti za materijale prema EC2. U tu svrhu koristićemo deo obimnih podataka eksperimenta uradjenih u USA i prikazanih u publikaciji 'Sigurnost konstrukcija' u prevodu Prof V.Brčića [2]. Na str.34 prikazan je histogram i kriva verovatnoće za čelik, a na str.36 za beton. $\mathrm{Za}$ beton se dobija odnos $\mathrm{f}_{\mathrm{cm}}{ }^{\prime} / \mathrm{f}_{\mathrm{ck}}{ }^{\prime}=5.48 / 3.47=1.57$, a za čelik $\mathrm{f}_{\mathrm{ym}}{ }^{\prime} / \mathrm{f}_{\mathrm{yk}}{ }^{\prime}=38.7 / 36.3=1.14$.

Dobijene su skoro potpuno iste vrednosti eksperimentom kao i vrednosti parcijalnih koeficijenata sigurnosti prema EC2, t.j. $\gamma_{\mathrm{cm}}=1.5$ za beton i $\gamma_{\mathrm{sm}}=1.15$ za čelik.

Može se zaključiti da su preko usvojenih klasa kvaliteta materijala pri dimenzionisanju preseka, parcijalni koeficijenti već uvedeni kao rezerva nosivosti preseka, pa ih ne treba dva puta uključiti u proračune, kao sto je predviđeno u EC2. Prema tome, P'87 ne primenjuje parcijalne koefijente za materijale, već taj efekat se dobija samo preko smanjenja kvaliteta materijala. Osnovnu rezervu nosivosti pri lomu daje odabrani globalni koeficijent sigurnosti za dejstva . Razliku izmedju P'87 i EC2 najlakše je pokazati preko brojnog primera.

Primer 1. Proračun momenta loma prema P'87 i EC2

Zadate su dimenzije preseka, armatura preseka, kvalitet materijala i radni moment savijanja. Treba naći moment loma preseka prma P'87 i prema EC2.

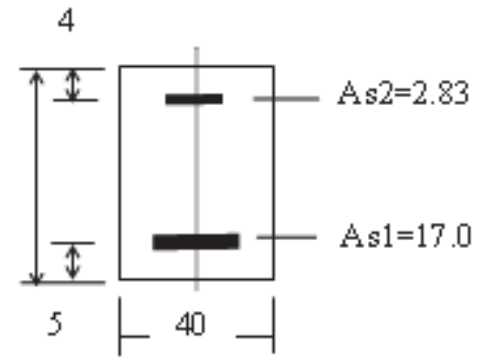

$$
\begin{aligned}
& \mathrm{f}_{\mathrm{ck}}=30[\mathrm{MPa}] \\
& \mathrm{f}_{\mathrm{Y}}=40\left[\mathrm{kN} / \mathrm{cm}^{2}\right] \\
& \mathrm{Mg}=48 \mathrm{kN} \mathrm{m} \\
& \mathrm{Mp}=240 \mathrm{kN} \mathrm{m} \\
& \mathrm{As} 1=17.00 ; \mathrm{a} 1=5 \mathrm{~cm} \\
& \mathrm{As} 2=2.83 ; \mathrm{a} 2=4 \mathrm{~cm}
\end{aligned}
$$

Primenom programa Construct $\mathrm{SECTION}^{4}$ (podprogam DPres) slede sledeći rezultati :

$\begin{array}{llll}\begin{array}{l}\mathrm{P}^{\prime} 87 \\ \mathrm{M}_{\mathrm{Ru}}\end{array} & \begin{array}{l}\mathrm{M}_{\mathrm{u}} \\ (\mathrm{kNM})\end{array} & \begin{array}{l}\mathrm{x} \\ (\mathrm{cm})\end{array} & \begin{array}{c}\text { GAMAu } \\ (\mathrm{kNm})\end{array} \\ 508.93 & 508.8 & 15.84 & 1.77 \\ & & & \\ \underline{\mathrm{EC} 2} & & & \\ \mathrm{M}_{\mathrm{d}} & \mathrm{M}_{\mathrm{u}} & \mathrm{x} & \text { GAMAu } \\ (\mathrm{kNm}) & (\mathrm{kNm}) & (\mathrm{cm}) & (-) \\ 425.04 & 424.8 & 20.71 & 1.48\end{array}$

Sada se može se naći odnos $\mathrm{M}_{\mathrm{Ru}}\left(\mathrm{P}^{\prime} 87\right) / \mathrm{M}_{\mathrm{d}}(\mathrm{EC} 2)=1.20$, odnosno vrednosti se razlikuju za $20 \%$. Ima primera u literaturi gde su razlike do $80 \%[9$ ].

\footnotetext{
${ }^{4} \mathrm{Na}$ sajtu GFS
} 


\section{ANALIZA RIZIKA RUŠENJA KONSTRUKCIJA}

U prethodnom izlaganju opisani su postupci zasnovani na globalnim ili parcijalnim koeficijentima sigurnosti, ali primena teorije verovatnoće se odnosi samo na određivanje kvaliteta materijala i određivanja radnih i slučajnih opterećenja. Posle nalaženja kvaliteta materijala postupak proračuna je deterministički. Ponekad se koristi izraz 'semiprobabilistički' postupak, koji je samo delimično tačan, jer su verovatno bolji termini koji su do sada upotrebljeni.

Glavni uslov u proračunu je $\mathrm{Su}<=\mathrm{S}_{\mathrm{Ru}}$ postavlja realnu potrebu da se, osim zadataka dimenzionisanja, razmotre rizici rušenja kao realna mogućnost i postave kriterijumi za stepene sigurnosti konstrukcija. Dosta široko je prihvaćeno, u našoj i svetskoj literaturi, da uvek postoji rizik rušenja ,odnosno da realne konstrukcije, projektovane prema sadašnjim normama, sa izvesnom verovatnoćom, ne garantuju nosivost. Ovo tvrđenje se može naći u radovima [ 7][9 ][10 ] [11 ] [12 ] i mnogim drugima, mada koriste tzv. 'koeficijet pouzdanosti' za procenu verovatnoće rušenja konstrukcije. Procena kvaliteta građevinskih materijala, najčešce, se obavlja pomoću teorije verovatnoće, pa se zato defininišu karakteristične vrednosti slučajnih veličina ( $u$ ovom radu to su čvrstoce materijala) i to za unapred željenu verovatnoću. Karakteristična vrednost se definise formulom:

, gde je

$$
x_{k}=\bar{x}+z \cdot \sigma
$$

$$
\begin{aligned}
& \bar{x} \text { - srednja vrednost čvstoće materijala } \\
& \mathrm{z} \text { - koeficijent odstupanja u odnosu na } \bar{x} \\
& \sigma \text { - standardno odstupanje od } \bar{x}
\end{aligned}
$$

Odstupanje u odnosu na $\bar{x}$ je $\Delta \mathrm{x}=\mathrm{z} \sigma$, odnosno $\mathrm{z}=\Delta \mathrm{x} / \sigma$. Za osnovne vrednosti $\mathrm{z}$ formirana je Tabela 2 sa vrednostima funkcije $\phi(z)$ - površine ispod krive raspodele $\mathrm{p}(\mathrm{z})$, odnosno relativne frekvencije slučajne veličine $\mathrm{z}$ u intervalu $(-3,+3)$. Videti krive raspodele za I slucaj koji vazi za graničnu nosivost preseka i krivu za II slučaj za radno opterećenje.

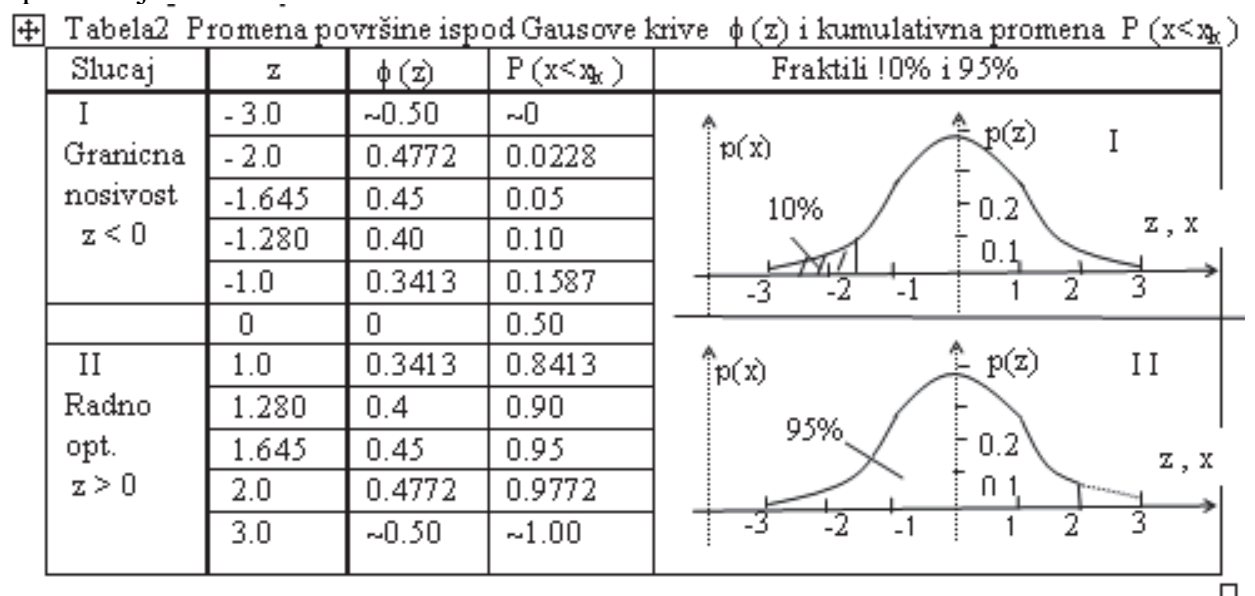


U praksi primene verovatnoće $u$ našoj zemlji (P'87) uvodi se faktor odstupanja $k=|k|=-z$ pa iz (3) sledi

$$
\begin{array}{ll}
x_{k}=\bar{x}-k \cdot \sigma & \text {-za otpornost preseka } \\
x_{k}=\bar{x}+k \cdot \sigma & \text { - za uticaje u preseku } .
\end{array}
$$

Polozaj karakteristične vrednosti za dejstva zavisı od ızabora traktila kada su ona najveća $\mathrm{P}\left(\mathrm{x}<\mathrm{x}_{\mathrm{k}}\right)$, a za graničnu nosivost uzima se za najniža vrednost željene verovatnoće. Zato postoje njihova dva položaja prema Sl.3.
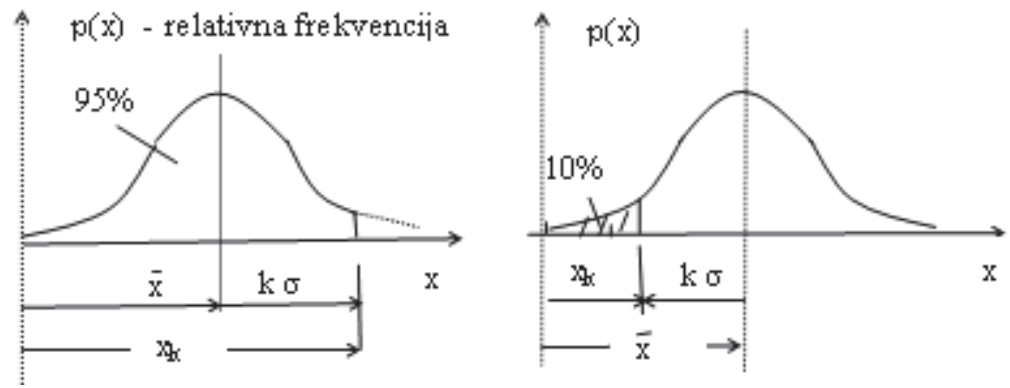

Sl. 3. Dva polozaja $x_{k}$. Fraktil ${ }_{95}$ i fraktil ${ }_{10}$ za promenjivu $x$

Ako se koriste podaci iz Tabele2 može se lako nacrtati kumulativna kriva, koja prikazuje potepeno povećanje verovatnoće u zavisnosti od promenjive x ili z (Sl.4)

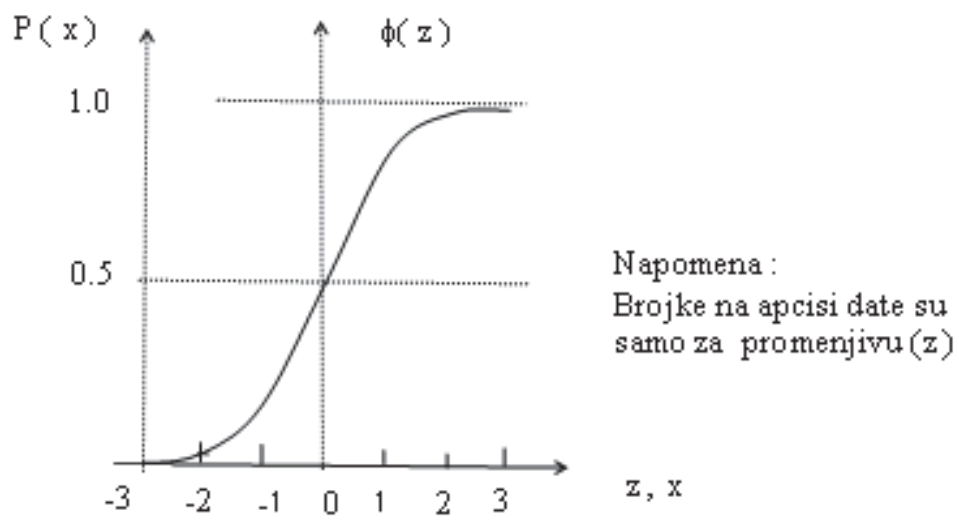

S1.4 Kumulativna kriva Gausove raspodele frekvencija

Poprečni presek ili konstrukcija može, u zavisnosti od graničnih vrednosti za uticaje $(\mathrm{Su})$ i nosivost $\mathrm{S}_{\mathrm{R}}$, imati tri stanja.

I. Stanje se definiše , na osnovu SL.5, sledećim uslovom 


$$
\mathrm{S}_{\mathrm{U}}{ }^{(\mathrm{I})}+\mathrm{Z}=\mathrm{S}_{\mathrm{Ru}} \quad \text { - prema } \mathrm{P}^{\prime} 87
$$

i uslovom

$$
\mathrm{S}_{\mathrm{d}}^{(\mathrm{I})}+\mathrm{Z}=\mathrm{S}_{\mathrm{Rd}} \quad \text { - prema EC2 }
$$

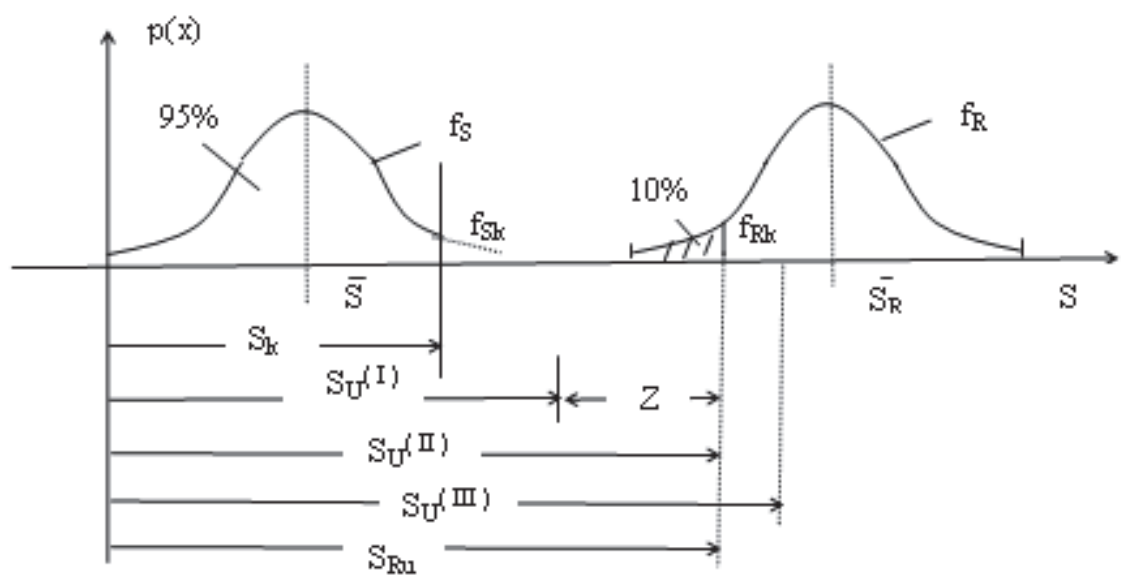

Sl.5 Položaj karakteristične vrednosti $S_{k}$, potrebnog graničnog momenta $S_{U}$ (tri mogućnosti) i položaj karakteristične granične otpornosti preseka $S_{R u}$

U izrazu (5a) je , gde je

$\mathrm{S}_{\mathrm{U}}^{(\mathrm{I})}=\gamma_{\mathrm{u}} \mathrm{S}=\sum \gamma_{\mathrm{ui}} \mathrm{S}_{\mathrm{i}} \quad$ - Potrebna granična sila nosivosti preseka

- $\quad \gamma_{\mathrm{u}}$ - Globalni koeficijent sigurnosti (Podaci iz Tabele 1 ili izraz(2))

- S - Zbir uticaja a za radno opterećenje konstrukcije (Podaci iz normi)

- Z - Dopunska rezerva granične nosivosti preseka .

U izrazu (5b) je za osnovni slučaj kombinacije opterećenja EC2:

$$
\mathrm{S}_{\mathrm{d}}^{(\mathrm{I})}=\gamma_{\mathrm{g}} \mathrm{G}+\gamma_{\mathrm{q}}\left(\mathrm{Q}_{\mathrm{k}, 1}+\sum \psi_{0 \mathrm{i}} \mathrm{Q}_{\mathrm{k}, 1}\right)-\text { računska sila preseka }
$$

Ovaj izraz se lako svodi na prethodni, ako se uvede oznaka $\gamma_{\mathrm{q}} \psi_{0 \mathrm{i}}=\gamma_{\mathrm{qi}} \psi_{\mathrm{i}}$.

Sila loma preseka je

$$
\mathrm{S}_{\mathrm{Ru}}=\mathrm{S}\left(\mathrm{f}_{\mathrm{ck}}, \mathrm{f}_{\mathrm{Yk}}, \mathrm{a}, \mathrm{b} \ldots \ldots\right) \quad \text { - prema } \mathrm{P}^{\prime} 87
$$

a računska sıla ıoma

$$
S_{R d}=S\left(f_{c k} / \gamma_{c}, f_{Y k} / \gamma_{Y}, a, b \ldots . .\right)-\text { prema EC2. }
$$


$S_{R d}$ se računa slično kao $S_{R u}[3]$, ali treba primeniti za matrijale $\gamma_{c}$ i $\gamma_{y}$.

Dopunska rezerva $(Z)$ se bira zbog želje projektanata i investitora da se imaju jače armirani preseci zbog vrste opterećenja ili zahteva da se kostrukcija bira prema monumentalnoj koncepciji objekta u odnosu na trajnost konstrukcije i dr.

II. Stanje se definiše uslovom $\mathrm{S}_{\mathrm{U}}{ }^{(\text {II })}=\mathrm{S}_{\mathrm{Ru}}$

Konstrukcija nema dopunsku rezervu nosivosti u odnosu na I.Slučaj.

Konstrukcija se nalazi u stanju granične ravnoteže .

III. Stanje se definiše uslovom $\mathrm{S}_{\mathrm{U}}^{(\text {III })}>\mathrm{S}_{\mathrm{Ru}}$

Konstrukcija nema dopunsku rezervu nosivosti u odnosu na I.Slučaj .Pored toga, postoji realna mogućnost rušenja konstrukcije.

Navedeni rezultati omogućavaju da se formira Tabela 3. za tri moguća stanja konstrukcije.

Tabela 3. Dopunska granična nosivost konstrukcije

\begin{tabular}{|c|c|c|c|c|}
\hline Stanje & $\mathrm{Z}$ & Uslovi & Konstrukcija & Rušenje \\
\hline I & $>0$ & $\mathrm{Su}<\mathrm{S}_{\mathrm{R}}$ & Sigurna & Isključeno \\
\hline II & $=0$ & $\mathrm{Su}=\mathrm{S}_{\mathrm{R}}$ & U ravnoteži & Moguće \\
\hline III & $<0$ & $\mathrm{Su}>\mathrm{S}_{\mathrm{R}}$ & Nesigurna & Izvesno \\
\hline
\end{tabular}

3 Formirana tabela olakšava izbor globalnog koeficijenta sigurnosti pri dimenzionisanju preseka u saglasnosti sa slučajevima od I do III. Potrebni koeficijenti se formiraju uzimajući vrednosti iz propisa ili, ponekad, po želji 4 projektanta za specijalne elemente konstrukcija (Stanje I.).

5 Rezistentni( Krajnji ) koeficijent sigurnosti definiše izraz

$$
\gamma_{R u}=\frac{S_{R u}}{S_{\text {serv }}}
$$

koji važi za usvojeni presek i armaturu .

Ako se postavi pitanje da li konstrukcija koja ispunjava uslove sigurnosti jednovremeno i pouzdana?

Odgovor je da ona osim sigurnosti treba da ispuni i uslove trajnosti i funkcionalnosti. Ovaj rad ne može dati opširniji odgovor kada se ispunjavaju uslovi trajnosti, odnosno koji se uslovi postavljaju od projektovanja do građenja i njihove eksploatacije, ali su danas u mnogim radovima precizirani iskustveni podaci za postupke kako da objekat postigne predviđeni vek trajanja (mere unapred predviđenih kontrola stanja konstrukcije[11] ). Osim toga, funkcionalost konstrukcije preko kontrole njenih pomeranja, dilatacija i drugih zahteva može se u dovoljnoj meri ispuniti [11]. 
Projektovani vek trajanja se svrstava u Modelu koda CEB-FIP(1978) u tri klase.

Tabela 4. Projektantski vek trajanja konstrukcija

\begin{tabular}{|l|l|}
\hline Vrsta konstrukcije & Projektantski vek trajanja \\
\hline Privremena & 5 godina \\
\hline Uobičajena & 50 godina \\
\hline Monumentalna & 500 godina \\
\hline
\end{tabular}

Vek trajanja u drugoj klasi veka trajanja, verovatno, je bolje uzeti od 50 do 250 godina. Projektantski vek trajanja od 50 godina, s' obzirom na iskustvo eksploatacije većine objekata, treba da bude veći. Može se predložiti interval od 50 do 250 godina.

Prva vrednost odgovara za pojavu prve veće intervencije na objektu, a druga odgovara proceni o potrebi da se izvrši rušenje konstrukcije ili njegova detaljna rekonstrukcija.

Postupak procene grešaka merenja pri ispitivanju nosača treba da bude predmet daljih istraživanja. Takođe, Tabela4. treba da bude data sa novim mogućim predlozima, ali mišljenja sam da nova rešenja treba da budu jednstavna za primenu, sa manje podataka po ugledu na navedeni kod.

\section{ZAKLJUČCI}

$\mathrm{Na}$ osnovu navedene analize mogu se doneti sledeći zaključci:

1. Teorija dopuštenih napona ima bar isti značaj kao Teorija ULS, što se često negira;

2. Teorija ULS se može koristiti u metodi parcijalnih koeficijenata na dva načina. Prvi način je strogo prema P'87, a drugi sa primenom globalnih koeficijenata sigurnosti [v.6];

3. Rad sa parcijalnim koeficijentima za materijale prema EC2 je neopravdan, jer je već probabilistički uveden radi usvajanja kvaliteta materijala ;

4. Ponovljen je predlog iz rada [ 5 ] da treba uvesti i globalni koeficijent sigurnosti jer može, ponekad, uspešnije da analizira odnos dve vrste opterećenja ;

5 Ne postoji rizik rušenja konstukcije, kao što se tvrdi u mnogim radovima[ 7 ] [9][10 ] [11 ] [12 ], ukoliko se zadrže uslovi predviđeni ispravnim projektom, ne samo zbog uspešnog rešenja konstrukcije, već i zbog usvojenog načina njenog održavanja i mogućnosti pregleda za radna opterećenja u toku veka njenog trajanja, pa konstrukcija postaje zbog toga i pouzdana ;

6 Postavljeni su jasni kriterijumi za mogućnost rušenja konstrukcja u zavisnosti od znaka dopunske rezerve opterećenja -funkcije Z ;

\section{LITERATURA}

[1] Evrokodovi EC1 i EC2, Gradjevinski fakultet, Beograd, 1994. 
[2] Reports of Kommittee on factors of safety(Prevod Prof.V.Brčića): Sigurnost konstrukcija,Građevinska knjiga, Beograd ,1963. V. 80, pg 279,1983.

[3] Jevtić D., Mihailović V. : Dalja istraživanja kostrukcija od $A B$ i $P B$ (Dimenzionisanje konstrukcija po teoriji loma) DGA-1085, Beograd, 1968

[4] Mihailović V., Grković S.: Koeficijenti sigumosti na lom preseka prema PBAB'87, Izgradnja 11, 5-11, 1989

[5] Mihailović V., Stipić L., Grković S.: Sigumost na lom AB preseka, Simpozijum JUDIMK- $a$, Novi Sad, sept, 1990

[6] Mihailović V. : Dimenzionisanje AB preseka, GF Subotica, 1993

[7] Milčić V. Probabilistički pristup dokazu nosivosti konstrukcija, Simpozijum JDGK Trogir, 1980

[8] Farkas G.,Kovach T.,Szalai K.,Lovas (Hung. groupFIB) : A.Historical background of probability-based design in Hungary Concrete structures, Vol 7, Budapest, 2006

[9] Aćić M. : Granična stanja nosivosti usled savijanja, podužne sile smicanja i torzije Savetovanje o Evrokodovima EC2, Beograd, 1995.

[10] Reports from FIB commissions and task groups: Commission 2.Safety and Performance concepts, Journal FIB, Nb3, Lozana 1999.

[11] Radić Jure : Betonske kostrukcije, Poglavlje str 463, Andris, Zagreb, 2010.

[12] Buđevac Dragan, Marković Zlatko...:Metalne konstrukcije, str 110, Građevinska knjiga, 2009.

[13] James MacGregor : Load and resistance factors for concrete design , ACI Journal, V. 80, pg 279,1983.

\section{APPLICATION AND IMPORTANCE THEORY OF PROBABILITY FOR SAFETY CONCRETE STRUCTURES}

Summary: Basic concepts analyses of safety concrete structures are shown by several methods actual and implemented in practice.

The aim of this paper is to specify possibilities of former methods analysis of safety and domain of their use. The observation is parallel given on reliability of concrete structures.

Keywords: Safety, RC structure, theory of probability, reliability 